\title{
Theoretical and methodological aspects in the information space of economic systems research
}

\author{
Anna Sergeevna Barakova \\ Vogograd State University \\ Volgograd, Russia
}

\author{
Ekaterina Viktorovna Kryukova \\ Astrakhan State University \\ Astrakhan, Russia \\ krukovae@mail.ru
}

\begin{abstract}
The highlighted characteristics of the information space in the framework of territorial, functional and evolutional approach are represented in the article. The term "information space" and its mental model in the framework of the functional and evolutionary approaches in the form of the conceptual model of the subject area give the opportunity and instruments for cooperation analysis of the economic relations entities.
\end{abstract}

Keywords- information space, regional economy, functional approach, mental model, hierarchical model of information space

\section{INTRODUCTION}

Being the recovery from a long time of crisis and the transition to a more complex level of self- organization, which occurs spontaneously and unevenly, the market structure formation of the Russian community and its building on the base of bottom-up self- organization, nevertheless obey general development laws. One of the visible manifestations of these laws is the complication of the information space structure as the reflecting of the economic space.

In view of the structural composition complexity in any large system the formation process of any of its subsystems takes different structural directions, which happens spontaneously and unevenly to a considerable extent. In such a situation the first-stage significance belongs to the level of information complexity of the system [1] . Information as one of the main mechanisms of system functioning and development is the most important system factor, which objectively determines the system's level of complexity.

The contemporary transformations in Russian economic system, the development of entrepreneurial activity and market structures, the necessity of efficient and competent decision-making are followed by the growth of demand for quality, trustworthy and prompt information. The satisfaction of this demand has become possible only on the basis of largescale informatization of the community as a whole and individual entities of different, primarily regional levels.

The increasing role of informatization of economic processes is the natural stage of the society's economic system evolution. The proposed by Inshakov O. conception of endogenous factors of production, which provide homeostasis of economic systems, defines information as one of the key factors conditioning economic development of the national mezolevel [2]. Since the factors grow out of the resources and conditions of economic management, actually they turn their effective transformation dominant into a product ensuring sustainable development of the given territory, forming "the nucleus of development".

The need for evaluation of the scale and level of information development becomes especially urgent, when information is treated as the most important and rare resource, factor and element of the economic potential of regional economic system, which should be effectively used for the achievement of its aims [3] .

\section{MATERIALS AND METHODS (MODEL)}

Systemic analysis of the role of information has been formed and expressed in the works of E. Schrödinger, P. Teilhard, N. I. Kobozev, N.N. Moiseev, N. Wiener, G. Gromov, D L'vov, J. Neyman, K, Shannon and W. Eshby among others. During the last years of the 20th century and the beginning of the 21 st particularly great attention is paid to the information factor in the contemporary domestic economics. The merit of such scholars as S. Avdashev, G. T. Artamonov, N.A. Kuznetsov, U.A. Shreider, J. Maiminas, A. Movsesyan, R.M. Nizhegorodsev, I. Peshhanskaya, A.A. Sidorov, V.F. Bainev, A.A. Shtrick lays undoubtedly in it.

A significant contribution to the research of the forming information space models and effective relations in it has been made by such foreign authors as M. Lehmann, D. Nort, G. Sella, K. Shapiro, B. Edmonds, as well as ome domestic authors such as T. Zakupen', A. Kiselev, T. Krichel, I. Ladenko, T. Nesterenko, S. Parinov, S. Starovit, V. Telerman and I. Shvetsov. The conceptual apparatus of the problem researched is analyzed by I. Andreev, I. Dzyaloshinskiy, N. Krivoshein, V. Lopatin, S. Nehaev, S. Yaskevich and others.

The problems of informatization and transformations of various kinds of activity by information economics are reflected in the works of R. Atkinson, J. Bradford, J. Galbraith, P. Drucker, K. Laudon, M. Castells, K. Kelley, D. Moskell, V. Mikhailovskiy, N. Moiseeva, A. Nove, D. Podolna, K. Page, V. Starbuck, A. Toffler, Ch. Freeman, , as 
well as T. Bogomolova, G. Kleiner, D L'vov, M. Frumkin, M. Heidegger, Yu. Khokhlov, R, Tsvylev, F. Shirokov, A. Shadrin, K. Jaspers and others.

However, the theories of information development, organization of specialized information systems of individual spheres, segments, sectors and markets have not been formed. Their potential and mechanisms of integration to the entire economic space of regional economics has not been studied.

The opportunities of exploiting the information methods of analysis for evaluation of the economic systems' development, the impact of information demands on regional economic development, the formation of conditions for providing the effectiveness of informatization have not been covered in domestic economics.

\section{RESULTS AND DISCUSSION}

The information development of regional economic systems in the parameters of the conceptual anthropocentric model "nature $\leftrightarrow$ human being $\leftrightarrow$ society" implies the purposeful, irreversible and consequent change of transformational and transactional factors of social production affected by information- communication technologies.

Information exchange and other kinds of information activity is the base for implementation and development of economic processes. A more advanced environment of information work, reducing the uncertainty of entities' business, allows them to obtain a higher level of possible resource exploitation effectiveness. The advance of Internet technologies and their exchange allows to involve more information resources, the usage of which provides quantitative and qualitative change of the cost structure and imposes new requirements to the technological component of the economic progress. Transaction costs are the parameters, defining the specificity of relations between entities of regional economic space. The nature of information exchange, being the essential feature of cooperation for these entities, is of crucial importance for their functioning. The information factor, along with the organizational and institutional factors, provides transactions, multiply uniting producers and consumers in the space of reproduction processes. In the information space this will be expressed in the nature of information interchange or the cooperation between the information systems of economic agents [4].

The above mentioned statements became the base for studying and structuring the information space and this has enabled the author to define it as a kind of space, admitting the endogeneity of its information factor. Such kind of space includes the relations between transactors concerning not only this factor, but the appropriate resources, conditions and products of their activity either. The information space evolves in the system of different factor spaces and reflects the information aspect of economic system functioning, connection and relations of its elements. The application of structural recursion to economic systems empowers us to get the endogenous information space of different levels, reflecting the aspects of their internal environment. Thus, the hierarchy of information spaces of different levels appears and covers the aspected subsytems' heterarchy inside each level, which conditions the internal cooperation, functioning and development.

The given point has allowed to form a hierarchical model of the information space, according to which the global information system represents a multilevel hierarchical system. On the primitive level of the hierarchical system's decomposition are the interdependent bodies of various subject-targeted information systems. In fact they are homogeneous, they take and process the data from the appropriate subject area [5].

The propriety of the theory of information space bases on the propositions of A. Kolmogorov, J. Neyman and V. Mogilevskiy. They proposed that "the information aspect defines the hierarchical pattern as the feature of the information system's structure... This hierarchical pattern allows to get one more degree of freedom for developing the systems. The development of various equal systems has become possible in a vertical sense." [6].

Such indications of self - organization as nonlinearity, non-equilibrium and heterogeneity, positive and negative retroactions, stability and instability, the lack and excess of resources are typical for each subsystem and structures in a developing system. That's why the higher the complexity and the hierarchical level of the subsystem, the stronger should the self- organization features and stability be reflected in a changing external environment. As the definition of information appears in connection with purposeful activities, its storage and structuring happens at the same time either with structuring and development of the whole economic system, either of its subsystems. Information structures of different orientation are generally adequate to the scale and orientation of practice. Consequently, the functioning of any organization structure is reflected in information structure.

Thereby, the development of regional economic systems will be unavoidably followed by a transition to a higher level of a contextually dependent understanding, defining and studying its information structure.

Solving the problem of the region's information development demands the awareness of new concepts of a common information space and information society. The fixation of new knowledge and its practical implementation in the form of new cultural values, institutional structures and high technologies demands multiple-aspect information reflecting and the introduction of regional economic systems. In turn, the integration of regional economic systems' information models conditions the formation and advance of a united information space.

In this connection, the solution of a number of urgent scientific problems becomes essential. So, these problems are: the further advance of a framework of important concepts, the elaboration of information development theories and management of information resources, the creation of information standard models and databases for different subject areas, adaptation of the formation concept and the development of a united information space in Russia and its regional peculiarities. 
In accordance with such understanding of the problem the main aims of information development can be formulated as the creation and maintenance of the information potential level, necessary for sustainable development. This should be implemented on the basis of information resources and stocks, which will provide the coordination of solutions, made by federal bodies of state power, territorial bodies and the bodies of local self-government.

The ensuring of a united economic space in the framework of the Federative state implies, on the one hand, taking account of regional peculiarities, the acceptance of the economic mechanism alternativeness and economic activities' norms in regions, on the other hand, the information transparency of administrational borders. Effective management and the control over the region's exploitation of resources can be achieved in the framework of a united information space by means of organizing an expert support system of the region. Therefore, the advance of the united structured information space of an economic system is one of the priority directions of Russian regional informatization.

Solving the mentioned problems will contribute to the creation of information society and be an essential condition of an economic system's sustainable development. Meanwhile it is necessary to take into consideration that global socialeconomic transformations are impossible without the development of a human being, which evolves as a systemic complex information object and being the models' central concept of sustainable development. The advance of regional and global communities, based on knowledge and innovations, depends on the cultural level, knowledge and the awareness of ongoing transformations.

The analysis of the "information system" category shows that many scholars treat the "information system" as a kind of a "territory", in other words, they incorporate this definition into a geopolitical aspect, in which "space" and "territory" act as fundamental definitions [7]. In the meaning of "information system", as we think, several different meaningforming approaches can be highlighted. The first is a traditional territorial approach, which says that that information space is the "informatized territory".

T. Zakupen' considers information space as "a territory, covered by information, information resources and infrastructure. In the framework of information space all entities have similar abilities of getting, transmitting and all other operations with information.”[8].

Examples of such definitions are also reflected in the work of E. Prokhorov, who clarifies that " information space is not just a territory, on which the cooperation of information data is implemented, but it is a space which has either geographical, either auditory characteristics" [9] . In our view, it would be more economically correct to speak about entities- users of information.

Thereby, in a territorial meaning the "information space" means a singled out territory, on which information resources, systems of accumulation, processing and disseminating of information are located, as well as the users of different kinds of resources, which jurisdictional according to the territory's existing legislation.

From the author's point of view, it is possible to single out the second approach to the exposure of the information space essence- the functional approach. This approach defines information space as the space of certain information cooperation.

Some scholars connect the category of "information space" with noospheric problematics. The vice-president of RAEN Professor S. Kapitsa has defined the information space as the materialization of the noosphere. In our view this is an important proposition, because it transfers many aspects of the definition from a technical to the social- economic area. $\mathrm{V}$. Vernadskiy points out that a human being needs a high scale of information opportunities for the achievement of the unity with the biosphere. In other words, he supposed that the information availability will general for the community as a whole [10]. According to Vernadskiy, the manmade information field will be one of the unity bases and a step in a man's transition to the noosphere [11]. The key thesis in this aspect is that the manmade information field is actually the main aspect of the noosphere. The given approach to the understanding of the information space was developed and institutionally formalized in "The formation and development conception of the united information space and appropriate state information resources of Russia". The elaboration of the conception took place in 1995 in pursuance of Russian President’s decree of 1July 1994 №1390 “On the enhancement of information- telecommunication on securing the bodies of state power and the order of their cooperation when implementing the public policy in the informatization sphere".

The authors of the conception point out that "information services, resources and software products (information potential) are unevenly spread in Russia and primarily in central regions. Such a position is determined by the distribution of the main Russian scientific and information centers and it does not take into account the needs of the population and administration. That is why the problem of balancing the information potential should be solved. The defined problems can be solved by a united information space in Russia [12] . In other words the authors of the Conception see the information space as certain resource pool of information, the provision means for their replenishment and processing, as well as the mechanisms for the users' access to these resources.

In the author's point of view, the given definition doesn't take into account the subject orientation of the information space, what consequently leads to its spontaneous organization. Also, the given interpretation doesn't reflect the necessity of organizing the systems of analytical processing and the representation of the information in a convenient form for different users.

It is worth mentioning that information products imply documentary information, prepared in accordance with users' needs and used to meet their requirements. Information services are the entities actions (the actions of owners and holders) aimed at supplying the users with information resources [13] . 
At the same time, the search and transmission of information, which is not documentary reflected but is present in people's intentions, plans, predictions and positions becomes more and more important. It is necessary to learn to take the information in a way, that the producer's identity is preserved.

From the cognition approach point of view the information processing is mediated by the system of categories or definitions which represent the world model. One of the first mentionings of such a way information environment analysis belongs to $\mathrm{B}$. Brooks. He wrote that the structure of knowledge is transformed during processing of the new information [14]. Thereby only information can change the structure of knowledge.

Analyzing different interpretations of the information space, it is worth noting that all authors gibe a plane and single-level definition of the information space. In our point of view, it contradicts the points of the systemic approach and doesn't cover the hierarchy, which is the main feature of the information space. By turn, the hierarchy is also the feature of self- organizing systems. Taking this into account, it will be more reasonable to represent the information space in the framework of the functional approach as a hierarchical selforganizing system and consequently to represent the definition of the information space as multi- level.

From the author's point of view, it is more rational to describe the information space as the form of subject- oriented information systems' integration, characterized by hierarchy, structural properties, extension and differentiation [15] .

The propriety of the suggested definition finds its corroboration in the works, in which authors emphasize the necessity of improving the structure of the information space [16] .

To the author's viewpoint, it is also necessary to point out the third- evolutionary approach to the analysis of the concept of information space. The entities of the information space cooperate the surrounding environment by filtering and processing the information. This process proceeds due to current information (mental) models which assure the understanding of the environment and the solution of arising problems.

The mental model of the information space, covering the economic space, is represented by the author in the form of the conceptual model of the subject area. This model can change in the process of storing the information evolutionarily and, thus it will have the opposite influence on functions and structures of the real economic. The more precisely the information model reflects the content of the information space, the higher its entities' potential of efficient functioning is. This is assured by the compliance principal of the information space with other factorial kinds of economic space. That is why it is reasonable to study the features, elements and mechanisms of forming and developing the aspected information space in various regional economic systems.

In fact, in our condition one more very often hidden factor, which determines the economic functioning effectiveness, appears. It is the availability of technical, institutional and organizational infrastructure, sustaining the functioning of each independent economic setup.

A significant share of economics' functioning bases on the information exchange between its entities and, consequently depends on conditions and parameters of the information flow development in the space of the economic system. The order of making direct information cooperation is the data and information flow exchange, which proceeds on the principals "one to all" and "all with all". This order is characteristic of online communities and their members. Such kind of cooperation runs through all spheres of social relations and its scientific description refers to the economic fundamentals.

\section{CONCLUSION}

Thereby, the regional economics' characteristics of the information space must systemically reflect the aspects of the information space in the framework of the territorial, functional and evolutionary approaches. If each of these approaches dominates, the information space is defined as:

- Static or full of content, it metrically characterizes the totality of differentiated entities and objects;

- Dynamic or active, it characterizes the integration features of the functioning objects and entities depending on their scale of structuring in a subject- oriented information system;

- Developing or irreversibly changing real subject area, represented in the adequate conceptual model, reflecting the targeted cooperation of its entities and objects in time.

The term "information space" and its mental model in the framework of the functional and evolutionary approaches in the form of the conceptual model of the subject area give the opportunity and instruments for cooperation analysis of the economic relations entities.

\section{References}

[1] A. Kalinina Theoretical and Methodological aspects in the development of information systems. Scientific and technical Information Processing. Allerton Press, Inc. 2008. T. 35 № 8. P. 50-54.

[2] O. Inshakov The Theory of Human Action and Economic Genetics / The Human Being in Contemporary Philosophical Conceptions / Cambridge Scholars Publishing, 2009. - 346p. (Р. 159-170).

[3] К. Лаудон., В. Старбук Организационная информация и знания / К. Лаудон, В. Старбук // Информационные технологии в бизнесе / Под редакцией М. Желены. - СПб.: Питер. - 2002. - С. 284-300.; Вальтух, К.К. Информационная теория стоимости /К.К. Вальтух. Новосибирск: Наука, 1996. 412 с; Ю.В. Яковец, Рента, антирента, квазирента в глобально-цивилизационном измерении /Ю.В. Яковец. - М.: ИКЦ «Академкнига», 2003. С. 141.; Урсул, А.Д. Природа информации. М.: Изд-во политической литературы, 1968. С.17.; Тамбовцев, В.Л. Пятый рынок: экономические проблемы производства информации. М.: Изд-во МГУ, 1993. С. 5-6.; Эрроу, К. Информация и экономическое поведение // Вопросы экономики. 1995. № 5. С. 100.; Стоуньер, Т. Информационное богатство: профиль постиндустриальной экономики // Новая технократическая волна на Западе / Т.Стоуньер. - М.: Прогресс, 1986. С. 393.; Goldfinger, Ch. Financial Markets as Information Markets: Preminary 
Exploration/ Paper prepared for the ENSSIB Conference Ëconomie de I'information». Lyon, May 20.

[4] А.Э. Калинина Развитие информационного пространства региональной хозяйственной системы / А.Э. Калинина. Волгоград: Изд-во ВолГУ, 2005. - 360с.; А.Э. Калинина. Развитие информационного пространства регионального рынка труда и занятости // Автореферат диссертации на соискание ученой степени доктора экономических наук по специальности 08.00.05 Экономика и управление народным хозяйством (5.Региональная экономика; 8. Экономика труда). - Волгоград, 2005. 56C.

[5] А.Э. Калинина. Теоретические аспекты исследования информационного пространства хозяйственной системы // Вестник ВолГУ. Серия 3. Экономика. Экология. Выпуск 10. - Волгоград: Изд-во ВолГУ, 2006г. С.17-23

[6] В.Д. Могилевский. Глобальное описание сложных динамических систем. / В.Д. Могилевский // Препринты ИПМ им. М.В. Келдыша РАН. Ч. 1,2. - 1992. - № 107. - С. 17.; В.Д. Могилевский. Методология систем: вербальный подход / В.Д. Могилевский. - М.: ОАО «Издательство «Экономика», 1999. - С. 45.

[7] И. Дзялошинский Информационное пространство России: политическая метафора или научное понятие// Право знать: история, теория, практика, N 7-8 (56-57), июль-август 2001 г.

[8] Т.В. Закупень Правовые и организационные аспекты формирования информационного пространства государств-участников СНГ / Т.В. Закупень. - М.: Молодая гвардия, 1998. - С. 20.

[9] Е.П. Прохоров Журналистика и демократия / Е.П. Прохоров. - М., 2001. - C. 192.

[10] В. И. Вернадский Несколько слов о ноосфере: В сб. Антология философской мысли. Русский Космизм / В.И. Вернадский. - М.: Педагогика-Пресс, 1993.
[11] В.И. Вернадский Биосфера и ноосфера / В.И. Вернадский. - М.: Рольф, 2002. -576 с

[12] Концепция формирования и развития единого информационного пространства России и соответствующих государственных информационных ресурсов. - М.: НТЦ «Информрегистр», 1996.

[13] Экономическая информатика: Введение в экономический анализ информационных систем: Учебник. - М.: ИНФРА-М, 2005. - 919 с.

[14] Б.С. Брукс Теоретическая информатика во втором этапе механизации процессов информационного поиска / Б.С. Брукс // Теоретические проблемы информатики. - 1979. - С. 12-25.

[15] А.Э. Калинина. Формирование и развитие информационного пространства региональных хозяйственных систем . Научная школа «Закономерности эволюции, способы трансформации и модернизации экономических систем». Монография. Авт. коллектив под ред. д-ра экон. наук, проф. Калининой А.Э. Волгоград: Изд-во ВолГУ, 2012. - 595 с.

[16] К. Лаудон , В. Старбук . Организационная информация и знания / К. Лаудон, В. Старбук // Информационные технологии в бизнесе / Под редакцией М. Желены. - СПб.: Питер. - 2002. - С. 284-300.; Ши Й. Интеллектуальный анализ данных. Информационные технологии в бизнесе / Под редакцией М. Желены. - СПб: Питер, 2002. - С. 612-619.; Абрамов В.А. Использование Интернеттехнологий при построении единого информационного пространства промышленного производства / В.А. Абрамов. Владивосток: Институт Автоматики и Процессов Управления; Ладенко И.С. Интеллектуальные системы в информатизации общества. Современная тенденция в инфовзаимодействии: Препр / И.С. Ладенко. - Новосибирск: АН СССР, Сиб. отд-ние, Ин-т истории, филологии и философии, $1988 .-78 \mathrm{c}$. 